\title{
The Role of Palmitoylation in Functional Expression of Nicotinic $\alpha 7$ Receptors
}

\author{
Renaldo C. Drisdel, Ehrine Manzana, and William N. Green \\ Department of Neurobiology, Pharmacology, and Physiology, University of Chicago, Chicago, Illinois 60637
}

\begin{abstract}
Neuronal $\alpha$-bungarotoxin receptors (BgtRs) are nicotinic receptors that require as yet unidentified post-translational modifications to achieve functional expression. In this study, we examined the role of protein palmitoylation in BgtR expression. BgtR $\alpha 7$ subunits are highly palmitoylated in neurons from brain and other cells capable of BgtR expression, such as pheochromocytoma 12 (PC12) cells. In PC12 cells, $\alpha 7$ subunits are palmitoylated with a stoichiometry of approximately one palmitate per subunit, and inhibition of palmitoylation blocks BgtR expression. In cells incapable of BgtR expression, such as human embryonic kidney cells, $\alpha 7$ subunits are not significantly palmitoylated. However, in these same cells, chimeric subunits with the N-terminal half of $\alpha 7$ fused to the C-terminal half of serotonin-3A receptor $\left(\alpha 7 / 5-\mathrm{HT}_{3 \mathrm{~A}}\right)$ subunits form functional BgtRs that are palmitoylated to an extent similar to that of BgtR $\alpha 7$ subunits in PC12 cells. Palmitoylation of PC12 and $\alpha 7 / 5-\mathrm{HT}_{3 \mathrm{~A}}$ BgtRs occurred during assembly in the endoplasmic reticulum (ER). In conclusion, our data indicate a function for protein palmitoylation in which palmitoylation of assembling $\alpha 7$ subunits in the ER has a role in the formation of functional BgtRs.
\end{abstract}

Key words: acetylcholine (ACh); bungarotoxin; nicotinic; palmitate; pheochromocytoma (PC12, PC-12); neuronal

\section{Introduction}

Ligand-gated ion channels (LGICs) are receptors that mediate fast transmission at synapses. Memory and learning require synaptic plasticity and restructuring, and recent studies indicate that synaptic strength may be controlled by changes in the number and density of LGICs. For example, in the CA1 region of the hippocampus, long-term synaptic change involves posttranslational modifications and alterations in trafficking of functional postsynaptic AMPA-type glutamate receptors (Barry and Ziff, 2002; Malinow and Malenka, 2002; Sheng and Kim, 2002). However, the molecular mechanisms that regulate LGIC expression at synapses remain essentially uncharacterized.

Nicotinic acetylcholine receptors (AChRs) are excitatory LGICs activated by the neurotransmitter acetylcholine and found in the peripheral nervous system and CNS as well as at the neuromuscular junction. Neuronal nicotinic receptors are composed of different $\alpha(\alpha 2-10)$ and $\beta(\beta 2-4)$ subunits and fall into two basic pharmacological categories: (1) high-affinity nicotine binding receptors or (2) high-affinity $\alpha$-bungarotoxin (Bgt) binding receptors (BgtRs). High-affinity nicotine binding receptors are predominantly $\alpha 4 \beta 2$-containing receptors in brain but also include $\alpha 3$ - and $\alpha 6$-containing receptors (Picciotto et al., 2001). BgtRs contain only $\alpha 7$ subunits (Drisdel and Green, 2000) and

Received Sept. 12, 2003; revised 0ct. 1, 2004; accepted 0ct. 5, 2004.

This work was supported by grants from the National Institutes of Health (National Institute on Drug Abuse and National Institute of Neurological Disorders and Stroke) and the Alzheimer's Association (W.N.G.). We are most grateful to Dr. Greg Jefford for assisting in the immunocytochemistry experiments and Dr. Paul Vezna for supplying the rat brains used in this study. We also thank members of the Green laboratory for their discussion and comments.

Correspondence should be addressed to William N. Green, Department of Neurobiology, Pharmacology, and Physiology, University of Chicago, 947 East 58th Street, Chicago, IL 60637. E-mail: wgreen@midway.uchicago.edu. D01:10.1523/JNEUROSCI.3315-04.2004

Copyright $\odot 2004$ Society for Neuroscience $\quad$ 0270-6474/04/2410502-09\$15.00/0 are unique among LGICs in that their expression is not cell autonomous. Although expression of BgtRs occurs throughout the nervous system (Sargent, 1993; McGehee and Role, 1995), and even in non-neuronal cells such as keritinocytes (Arrendondo et al., 2002), $\alpha 7$ subunits cannot form functional BgtRs in most mammalian cells used for heterologous expression (Cooper and Millar, 1997; Rangwala et al., 1997). In cultured cells such as pheochromocytoma 12 (PC12) cells in which functional BgtR expression occurs (Blumenthal et al., 1997; Rangwala et al., 1997), $\alpha 7$ subunits are folded and processed into conformations not achieved in cells in which no BgtR expression is observed, such as human embryonic kidney (HEK) cells (Rakhilin et al., 1999). In HEK cells, BgtR expression can be rescued by replacing the transmembrane and cytoplasmic domains of $\alpha 7$ with those of the serotonin-3A receptor subunit $\left(\alpha 7 / 5-\mathrm{HT}_{3 \mathrm{~A}}\right.$ chimera) (Corringer et al., 1995). These subunits are processed much the same as endogenous $\alpha 7$ subunits in PC12 cells and rat brain (Rakhilin et al., 1999; Drisdel and Green, 2000) and therefore provide a good model system in which to study the post-translational processing required for BgtR expression.

In this study, we identified palmitoylation as a posttranslational modification involved in the functional expression of BgtRs. Palmitoylation is a reversible, post-translational process in which palmitate is covalently attached to cysteine residues. Interest in palmitoylation has increased with the discovery of its role in regulating the function and subcellular localization of synaptic proteins and proteins involved in signal transduction (El-Husseini and Bredt, 2002; Linder and Deschenes, 2003; Qanbar and Bouvier, 2003). Here, we make use of new, more sensitive methods for labeling palmitoylation sites that allow the stoichiometry of palmitoylation to be measured and for palmitoylation of proteins purified from brain to be assayed (Drisdel and Green, 
2004). Evidence is presented for a novel function for protein palmitoylation in which subunit palmitoylation occurs in the endoplasmic reticulum (ER) during BgtR assembly, resulting in the formation of functional receptors.

\section{Materials and Methods}

Subunit constructs, cell lines, and transfection. Hemagglutinin (HA) epitope-tagged chick $\alpha 7$, mouse $5-\mathrm{HT}_{3 \mathrm{~A}}$, and $\alpha 7 / 5-\mathrm{HT}_{3 \mathrm{~A}}$ subunit cDNAs in a pMT3 expression vector (Swick et al., 1992) were described previously (Rakhilin et al., 1999). The human kidney epithelial cell line tsA201 (HEK cells) was maintained in DMEM supplemented with $10 \%$ calf serum (Hyclone, Logan, UT). HEK cells were transiently transfected with the subunit cDNA constructs using a calcium phosphate protocol (Eertmoed et al., 1999). PC12 N21 cells, also referred to as PC12-C cells (PC12 cells) (Blumenthal et al., 1997), were a gift from Dr. Richard Burry (Ohio State University, Columbus, $\mathrm{OH}$ ). The cells were cultured in DMEM containing $5 \%$ heat-inactivated horse serum and $10 \%$ fetal bovine serum (Hyclone).

Metabolic labeling. Cell cultures were incubated in methionine-free DMEM for 10-15 min and pulse labeled in methionine-free DMEM containing $100 \mu \mathrm{Ci} / \mathrm{ml}$ of ${ }^{35} \mathrm{~S}$-methionine-cysteine $\left(\mathrm{EXPE}^{35} \mathrm{~S}^{35} \mathrm{~S}\right.$; NEN, Boston, MA). Cells were washed with DMEM supplemented with $5 \mathrm{mM}$ unlabeled methionine and incubated at $37^{\circ} \mathrm{C}$ in culture medium for the indicated chase periods. For ${ }^{3} \mathrm{H}$-palmitate labeling, palmitic acid [10, $11-{ }^{3} \mathrm{H}$ ] (10 mCi/ml; American Radiolabeled Chemicals, St. Louis, MO) in ethanol was concentrated under nitrogen at $4^{\circ} \mathrm{C}$ to a volume not to exceed $5 \%$ in the labeling medium. DMEM containing $1 \%$ calf serum was added to the vial, vortexed vigorously, and diluted to a final activity of $100 \mu \mathrm{Ci} / \mathrm{ml}$. This labeling medium was added to cell cultures $(1 \mathrm{ml}$ per $6 \mathrm{~cm}$ plate) and incubated for $4 \mathrm{hr}$ at $37^{\circ} \mathrm{C}$.

Radiolabeled proteins were run on $4-8 \%$ SDS-PAGE and transferred to nitrocellulose membranes or gels were fixed, treated with Amplify (Amersham Biosciences, Arlington Heights, IL) for $30 \mathrm{~min}$, dried, and exposed to Kodak (Rochester, NY) XRP or BioMax film at $-70^{\circ} \mathrm{C}$ with intensifying screen. Membranes were dried and exposed to a Phosphor Screen (Molecular Dynamics, Sunnyvale, CA) and scanned on a PhosphorImager. Quantification of band intensities was performed using ImageQuant (Molecular Dynamicszcomx) software.

Solubilization, affinity purification, and glycosidase treatment. Rat brain membranes were prepared as described previously (Drisdel and Green, 2000). Brain membrane preparations or cultured cells were solubilized in lysis buffer ( $150 \mathrm{~mm} \mathrm{NaCl}, 5 \mathrm{~mm}$ EDTA, $50 \mathrm{~mm}$ Tris, pH 7.4, 0.02\% $\mathrm{NaN}_{3}$ ) containing $1 \%$ Triton X-100 (TX100), 2 mm phenylmethylsulfonyl fluoride, $10 \mu \mathrm{g} / \mathrm{ml}$ each of chymostatin, pepstatin, leupeptin, and tosyl-lysine chloromethylketone, and $50 \mathrm{~mm} N$-ethylmaleimide (NEM). Lysates were clarified by centrifugation at $10,000 \times g$ for $30 \mathrm{~min}$ at $4^{\circ} \mathrm{C}$. The supernatants were incubated with Sepharose $4 \mathrm{~B}$ or Protein G Sepharose (Amersham Biosciences) to remove nonspecifically bound proteins. The beads were removed by centrifugation, and the supernatants were rotated overnight with either saturating amounts of the anti-HA antibody (mAb 12CA5) or $\alpha$-Bgt-Sepharose. Bgt-Sepharose was prepared by coupling Bgt to cyanogen bromide-activated Sepharose 4B (Amersham Biosciences) according to the manufacturer's protocol. The receptorantibody complex was precipitated with Protein G-Sepharose. For glycosidase experiments, the affinity-purified proteins were treated with 1-5 $\mathrm{U}$ of endoglycosidase $\mathrm{H}$ (endoH) (Calbiochem, La Jolla, CA) at $30^{\circ} \mathrm{C}$ for $36 \mathrm{hr}$.

2-Bromopalmitate treatment and ${ }^{125} I$ - $\alpha$-bungarotoxin binding. PC12 cells were cultured in 12 well plates. To measure the appearance of new cell-surface receptors, pre-existing cell-surface BgtRs were blocked by binding with unlabeled Bgt $(10 \mathrm{~nm})$. Cells were then rinsed twice with DMEM and incubated at $37^{\circ} \mathrm{C}$ in $2 \mathrm{ml}$ of culture medium containing the indicated concentrations of 2-bromopalmitate (2-BP) (Aldrich Chemicals, Milwaukee, WI). The cells were harvested at the indicated times, after which ${ }^{125} \mathrm{I}$-Bgt binding to newly inserted surface receptors was performed in PBS for $1 \mathrm{hr}$ in $4 \mathrm{~nm}{ }^{125} \mathrm{I}$-Bgt at room temperature. To measure the formation of intracellular BgtRs at the different concentrations of 2-BP, cell-surface BgtRs were again blocked by binding with unlabeled Bgt (10 nм), and cell-surface receptors were depleted from the lysate with anti-Bgt antibodies. Lysates devoid of surface receptors were incubated at $4^{\circ} \mathrm{C}$ overnight in the presence of $10 \mathrm{nM}{ }^{125} \mathrm{I}$-Bgt and ${ }^{125} \mathrm{I}$ Bgt-bound intracellular BgtRs precipitated with concanavalin A-Sepharose. To measure the turnover rate of cell-surface receptors, intact cells were incubated with ${ }^{125} \mathrm{I}-\mathrm{Bgt}$, as above. Plated cells were washed twice with DMEM and incubated at $37^{\circ} \mathrm{C}$ in culture medium containing the indicated concentrations of 2-BP. At different time points, the culture medium was collected to assess the amount of radiolabel released caused by receptor internalization and degradation of ${ }^{125} \mathrm{I}$ Bgt. ${ }^{125} \mathrm{I}$-Bgt counts were measured using a LKB-Wallac (Gaithersburg, MD) 1470 automatic gamma counter. At the concentrations used, no differences in morphology or cell number were observed for cells cultured in the presence or absence of 2-BP.

${ }^{3} \mathrm{H}-\mathrm{N}$-ethylmaleimide labeling to assay palmitoylation. Palmitoylated proteins were labeled as described previously (Drisdel and Green, 2004). Briefly, NEM [ethyl-1, 2- ${ }^{3} \mathrm{H}$ ] (1 mCi/ml; NEN) supplied in pentane was kept in a methanol-dry ice bath and diluted with absolute ethanol to a final concentration of $5 \mu \mathrm{M}(0.25 \mathrm{mCi} / \mathrm{ml})$. Affinity-purified protein bound to protein G-Sepharose or Bgt-Sepharose was treated with $1 \mathrm{M}$ hydroxylamine, $\mathrm{pH} \mathrm{7.4,} \mathrm{for} 1 \mathrm{hr}$ at room temperature. Controls were incubated in the presence of $1 \mathrm{~m}$ Tris, $\mathrm{pH}$ 7.4. Beads were washed twice with lysis buffer containing $1 \%$ TX100, resuspended in 8 vol of the same buffer containing $0.5 \mu \mathrm{M}{ }^{3} \mathrm{H}-\mathrm{N}$-ethylmaleimide $\left({ }^{3} \mathrm{H}-\mathrm{NEM}\right)$, and rotated at room temperature for $3 \mathrm{hr}$. Samples were run on $4-8 \%$ SDS-PAGE and transferred to nitrocellulose membranes. After blotting, membranes were dried and exposed to a ${ }^{3} \mathrm{H}$-specific Phosphor Screen for $4 \mathrm{~d}$ and scanned on a PhosphorImager. Quantification of scans was performed using ImageQuant software. Immunoblots were performed on the same membranes or on samples prepared in parallel. Immunoblots were probed with polyclonal goat anti- $\alpha 7$ or rabbit anti-HA antibodies (Santa Cruz Biotechnology, Santa Cruz, CA) and visualized with an enhanced chemiluminescent kit (Amersham) using horseradish peroxidaseconjugated secondary antibodies.

To measure the stoichiometry of palmitoylation, the specific activity of the $0.5 \mu \mathrm{m}$ stock ${ }^{3} \mathrm{H}-\mathrm{NEM}$ (cpm per picomol) was determined by scintillation counting (LS6500; Beckman Instruments, Fullerton, CA). After labeling, the total cpm of ${ }^{3} \mathrm{H}-\mathrm{NEM}$ incorporated into each sample was measured by scintillation counting, and the number of picomoles of ${ }^{3} \mathrm{H}-\mathrm{NEM}$ was determined using the specific activity of the stock solution. These values were divided by the amount of BgtRs in each labeled sample, which was estimated by the amount of ${ }^{125} \mathrm{I}$-Bgt bound at a stoichiometry of $4-5$ pmol Bgt per pmol of receptor ( $\sim 1$ pmol per subunit) (Rangwala et al., 1997). To estimate the amount of HA-tagged $\alpha 7$ or $5-\mathrm{HT}_{3 \mathrm{~A}}$ subunits expressed in HEK cells, immunoblots with anti-HA antibodies were quantified by densitometry and compared with immunoblots of a known level of ${ }^{125} \mathrm{I}$-Bgt-binding HA-tagged $\alpha 7 / 5-\mathrm{HT}_{3 \mathrm{~A}}$ subunits. To quantify the amount of $\alpha 7$ subunits expressed in PC12 cells, immunoblots with anti- $\alpha 7$ antibodies were quantified by densitometry and compared with blots of a known level of ${ }^{125} \mathrm{I}$-Bgt binding $\alpha 7$ subunits.

Fluorescence microscopy. Transfected cells and PC12 cells were grown on coverslips and fixed in 4\% paraformaldehyde. Cells were permeabilized with $0.1 \%$ TX100 and blocked with tris buffered saline (TBS) supplemented with $2 \mathrm{mg} / \mathrm{ml} \mathrm{BSA}$ (TBS/BSA). Primary and secondary antibodies, as well as biotinylated Bgt (btn-Bgt) (Molecular Probes, Eugene, OR), streptavidin 488 (strep488) (Molecular Probes), and tetramethylrhodamine-labeled Bgt (TMR-Bgt) (Molecular Probes), were diluted in TBS/BSA. Cells were dually stained with TMR-Bgt or btn-Bgt (300 nM) to visualize BgtRs and a mouse monoclonal anti-KDEL antibody (1:100) (Stressgen Biotechnologies, San Diego, CA) to stain ER compartments. The secondary fluoroscein isothiocyanate-labeled goat anti-mouse (Molecular Probes) and strep488 were used at 1:500. Specimens were mounted in Vectashield (Vector Laboratories, Burlingame, CA) and scanned on an IX70 Olympus (Melville, NY) Fluoview 200 laserscanning confocal microscope using a $60 \times$ planApo (numerical aperture, 1.4; oil) objective. Images were analyzed using NIH Image J software (National Institutes of Health, Bethesda, MD). 
a

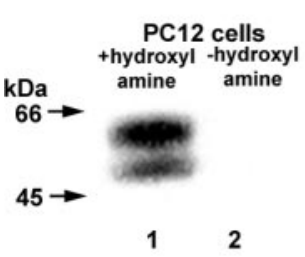

b

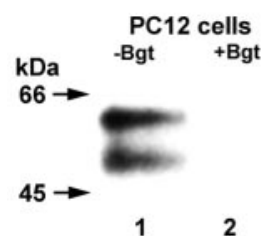

3H-NEM labeled

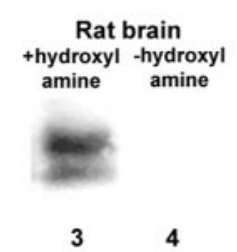

Immunoblot

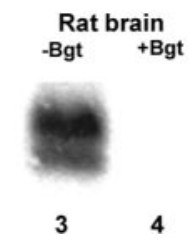

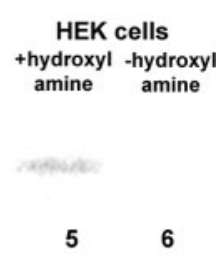

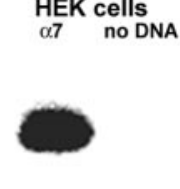

5

Figure 1. Palmitoylation of $\alpha 7$ subunits in different cell types. $a, \alpha 7$ subunits expressed in PC12 cells (lanes 1 and 2), rat brain (lanes 3 and 4), or HEK cells (lanes 5 and 6 ) were purified and palmitoylation was assayed by labeling with ${ }^{3} \mathrm{H}-\mathrm{NEM}$. $\alpha 7$ subunits in $\mathrm{PC} 12$ cells and rat brain, which form functional BgtRs, were purified with Bgt-Sepharose and were palmitoylated as assayed by ${ }^{3} \mathrm{H}$-NEM labeling. $\alpha 7$ subunits in HEK cells, which do not form functional BgtRs, were purified with anti-HA antibodies and showed almost nondetectable levels of palmitoylation, as assayed by ${ }^{3} \mathrm{H}$-NEM labeling. As shown previously (Rakhilin et al., 1999; Drisdel and Green, 2000), $\alpha 7$ subunits in BgtRs migrated as a doublet centered at $55 \mathrm{kDa}(a, b$, lanes 1 and 3), whereas $\alpha 7$ subunits expressed in HEK cells migrated as a single band at $55 \mathrm{kDa}$. No ${ }^{3} \mathrm{H}-\mathrm{NEM}$ labeling was detected without hydroxylamine treatment (-hydroxylamine; lanes 2, 4, and 6), demonstrating the specificity of the ${ }^{3} \mathrm{H}$-NEM labeling. $b, \alpha 7$ subunit expression in $\mathrm{PC} 12$ cells (lanes 1 and 2), rat brain (lanes 3 and 4), or HEK cells (lanes 5 and 6) was monitored using immunoblot analysis. The subunits were purified as in $a$, and immunoblots were stained with anti- $\alpha 7$ (lanes 1-4) or anti-HA antibodies (lanes 5 and 6). The addition of excess unconjugated Bgt completely blocked receptor binding to the Bgt-Sepharose (lanes 2 and 4). Based on ${ }^{125}$ Bgt binding, approximately equal amounts (1-2 pmol) of $\mathrm{PC} 12$ or rat brain $\alpha 7$ receptor were loaded in each lane. For $\alpha 7$ subunits in HEK cells, subunits from one confluent $6 \mathrm{~cm}$ plate were loaded in each lane.

\section{Results}

\section{BgtR $\alpha 7$ subunits are palmitoylated}

To investigate whether palmitoylation has a role in BgtR expression, we compared the palmitoylation of endogenous $\alpha 7$ subunits from PC12 cells, in which $\alpha 7$ subunits assemble into BgtRs, to that of $\alpha 7$ subunits expressed heterologously in the HEK cells, in which BgtRs do not form. Using a PC12 cell variant that expresses relatively large numbers of BgtRs (Rangwala et al., 1997), attempts to metabolically label BgtRs with ${ }^{3} \mathrm{H}$-palmitate were inconclusive (data not shown). We have recently developed alternative assays of protein palmitoylation based on hydroxylamine cleavage of the thioester bond between the fatty acid and cysteine side chain followed by reaction of the newly generated free sulfhydryl with sulfhydryl-specific reagents, such as ${ }^{3} \mathrm{H}$ NEM. These techniques are significantly more sensitive than metabolic labeling with ${ }^{3} \mathrm{H}$-palmitate and can be used quantitatively to measure levels of protein palmitoylation (Drisdel and Green, 2004). PC12 cells were solubilized in the presence of unlabeled NEM to alkylate preexisting sulfhydryls. BgtRs were then purified with Bgt-Sepharose affinity resin, treated with hydroxylamine, and subsequently labeled with ${ }^{3} \mathrm{H}-\mathrm{NEM}$. As shown in Figure 1, ${ }^{3} \mathrm{H}$-NEM-labeled BgtRs migrated as two closely spaced bands centered at $55 \mathrm{kDa}$ (Fig. $1 a$, lane 1). These two bands comigrated with $\alpha 7$ subunit doublet bands detected by anti- $\alpha 7$ antibody on immunoblots of PC12 BgtRs (Fig. 1b, lane 1). Samples that were not treated with hydroxylamine were not labeled

Table 1. Estimated stoichiometry of palmitoylation

Picomoles of ${ }^{3} \mathrm{H}-\mathrm{NEM}$ per picomoles of subunit

\begin{tabular}{ll}
\hline Whole cell & \\
BgtR $\alpha 7$ subunits in PC12 cells & $1.0 \pm 0.1^{a}$ \\
$\alpha 7$ subunits in HEK cells & $0.015^{b}$ \\
$5-\mathrm{HT}_{3 \mathrm{~A}}$ subunits in HEK cells & $1.2^{b}$ \\
$\alpha 7 / 5-\mathrm{HT}_{3 \mathrm{~A}}$ subunits in HEK cells & $1.4 \pm 0.1^{a, c}$ \\
Subcellular fractions in PC12 cells & \\
$\quad$ Cell-surface BgtR $\alpha 7$ subunits & $0^{b}$ \\
$\quad$ Intracellular BgtR $\alpha 7$ subunits & $2.5^{b}$ \\
$\quad$ Unassembled $\alpha 7$ subunits & $0.6^{b}$ \\
Subcellular fractions in $\mathrm{HEK}_{\text {cells }}$ & \\
$\quad$ Cell-surface BgtR $\alpha 7 / 5-\mathrm{HT}_{3 \mathrm{~A}}$ subunits & $0.15 \pm 0.03^{a}$ \\
Intracellular BgtR $\alpha 7 / 5-\mathrm{HT}_{3 \mathrm{~A}}$ subunits & $2.2 \pm 0.3^{a}$ \\
$\quad$ Unassembled $\alpha 7 / 5-\mathrm{HT}_{3 \mathrm{~A}}$ subunits & $0.36 \pm 0.04^{a}$ \\
\hline
\end{tabular}

${ }^{a}$ Average \pm SD; $n=3-4$.

${ }^{b}$ Average of $n=2$. Units: picomoles of ${ }^{3} \mathrm{H}-\mathrm{NEM}$ were determined by scintillation counting. Picomoles of subunits for BgtRs are equal to picomoles of ${ }^{125} \mathrm{I}-\mathrm{Bgt}$ bound at a stoichiometry of $4-5 \mathrm{pmol}$ Bgt per pmol of receptor (Rangwala et al., 1997). To estimate the number of picomoles of subunits for $\alpha 7$, unassembled $\alpha 7 / 5-\mathrm{HT}_{3 \mathrm{~A}}$, and $5-\mathrm{HT}_{3 \mathrm{~A}}$ subunits in $\mathrm{HEK}$ cells, immunoblots of these subunits were quantified by densitometry and compared with blots of a known level of ${ }^{125} \mathrm{I}-\mathrm{Bgt}$-bound $\alpha 7 / 5-\mathrm{HT}_{3 \mathrm{~A}}$ subunits. To estimate the number of picomoles of unassembled $\alpha 7$ subunits in PC12 cells, immunoblots of these subunits were quantified by densitometry and compared with blots of a known level of ${ }^{125} \mathrm{I}$-Bgt-bound $\alpha 7$ subunits.

'Measured $12 \mathrm{hr}$ after transfection (Drisdel and Green, 2004).

with ${ }^{3} \mathrm{H}$-NEM (Fig. 1a, lane 2), indicating that ${ }^{3} \mathrm{H}-\mathrm{NEM}$ is specifically labeling palmitoylation sites on $\alpha 7$ subunits.

In parallel, we assayed the palmitoylation of HA epitopetagged $\alpha 7$ subunits expressed in HEK cells in which the $\alpha 7$ subunits fail to assemble into functional BgtRs. Based on immunoblot analysis, $\alpha 7$ subunit expression in these cells (Fig. 1b, lane 5) was much higher than BgtR $\alpha 7$ levels obtained in PC12 cells (Fig. $1 b$, lane 1). However, the level of ${ }^{3} \mathrm{H}-\mathrm{NEM}$ incorporated into $\alpha 7$ subunits in HEK cells was significantly less than that incorporated into PC12 BgtR subunits (Fig. 1a, compare lanes 1 and 5). In PC1 2 cells, the $\alpha 7$ subunits had a stoichiometry of $1.0 \mathrm{pmol}$ palmitate per pmol subunit, whereas the stoichiometry of $\alpha 7$ subunits in HEK cells was 0.015 pmol palmitate per pmol subunit, 67-fold less than in the PC12 cells (Table 1).

Using our techniques to assay protein palmitoylation, we were also able to assay the palmitoylation of BgtRs purified from rat brain. Live cells are required for the most common assay of palmitoylation, metabolically labeling with ${ }^{3} \mathrm{H}$ - or ${ }^{125} \mathrm{I}$-palmitate. Consequently, only two proteins, myelin proteolipids (Bizzozero et al., 2002) and synaptosomal protein of $25 \mathrm{kDa}$ (SNAP-25) (Drisdel and Green, 2004), have been shown to be palmitoylated in vivo in brain. Rat brain membranes were solubilized in the presence of unlabeled NEM. BgtRs were then purified from brain lysates with Bgt-Sepharose affinity resin, treated with hydroxylamine, and labeled with ${ }^{3} \mathrm{H}-\mathrm{NEM} .{ }^{3} \mathrm{H}-\mathrm{NEM}$ specifically labeled brain BgtR palmitoylation sites (Fig. 1 $a$, lane 3) because no labeling was observed in samples that were not treated with hydroxylamine (Fig. 1a, lane 4). Rat brain BgtRs are composed of $\alpha 7$ subunits (Drisdel and Green, 2000), and both the ${ }^{3} \mathrm{H}-\mathrm{NEM}$ labeled protein and immunoblot analysis using anti- $\alpha 7$ antibodies (Fig. 1b, lanes 3 ) show the same doublet pattern and molecular weight observed with the $\alpha 7$ subunits purified from PC12 cells (Fig. 1a,b, lane 1).

\section{Inhibition of palmitoylation blocks BgtR formation}

To further address whether $\alpha 7$ subunit palmitoylation has a role in BgtR expression, we tested the effect of blocking palmitoylation in PC12 cells. $\alpha 7$ subunit palmitoylation was blocked by application of 2-BP, which is a specific inhibitor of protein palmitoylation (Coleman et al., 1992; Webb et al., 2000; El-Husseini 
a

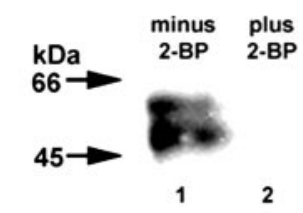

C

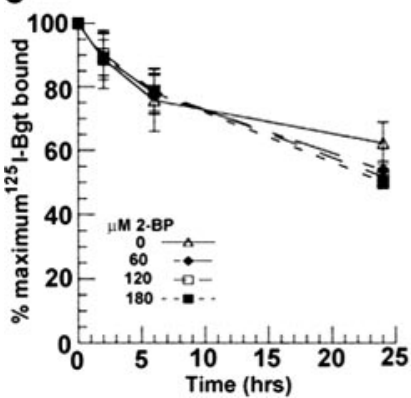

b

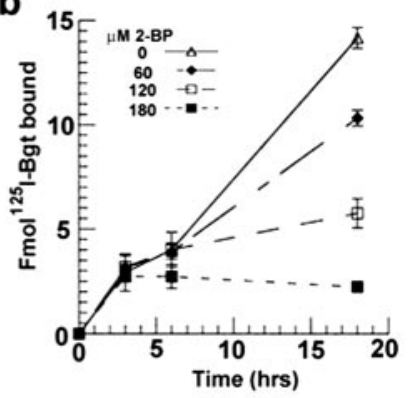

d

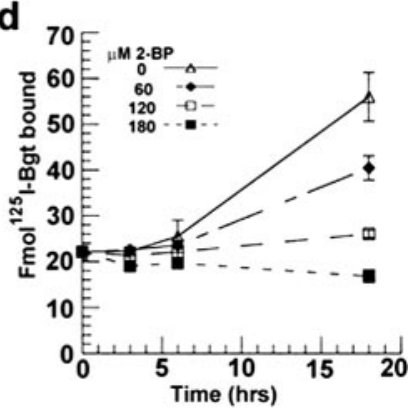

Figure 2. The inhibitor of palmitoylation, 2-BP, blocks $\alpha 7$ subunit palmitoylation and BgtR expression in PC12 cells. a, 2-BP blocks $\alpha 7$ subunit palmitoylation. Palmitoylation of $\alpha 7$ subunits from PC12 cells was assayed using ${ }^{3} \mathrm{H}-\mathrm{NEM}$ labeling, as in Figure $1 a$. PC12 cells were treated without (lane 1) and with $120 \mu \mathrm{m}$ 2-BP (lane 2). b, 2-BP blocks the arrival of new BgtRs at the $\mathrm{PC} 12$ plasma membrane. BgtR surface expression was measured by ${ }^{125} \mathrm{I}$-Bgt binding after treating PC12 cells with the indicated concentrations of 2-BP. C, 2-BP did not affect turnover of $P C 12$ surface BgtRs. Turnover was measured from the rate of ${ }^{125}$ I released after internalization and degradation of ${ }^{125} \mathrm{I}$-Bgt-bound receptors after treating PC12 cells with the indicated concentrations of 2-BP. d, 2-BP blocks formation of new intracellular Bgt binding sites measured by ${ }^{125} \mathrm{I}$-Bgt binding after treating PC12 cells with the indicated concentrations of 2-BP. Each point in $b, c$, and $d$ represents the mean $\pm S D(n=3)$.

et al., 2002). The degree to which 2-BP treatment blocked $\alpha 7$ subunit palmitoylation was assayed by using our ${ }^{3} \mathrm{H}-\mathrm{NEM}$ method of labeling palmitoylation sites. Within the error of our measurements, incubation of PC12 cells with $120 \mu \mathrm{M} 2-\mathrm{BP}$ totally inhibited $\alpha 7$ subunit palmitoylation, as determined by ${ }^{3} \mathrm{H}-\mathrm{NEM}$ labeling (Fig. 2a).

Several different assays were performed to test the effects of blocking $\alpha 7$ subunit palmitoylation in PC12 cells. First, we tested whether inhibition of $\alpha 7$ subunit palmitoylation altered the arrival of BgtRs at the cell surface. To monitor surface receptor expression, pre-existing receptors were blocked with unlabeled Bgt. Newly inserted BgtRs were detected by binding with ${ }^{125} \mathrm{I}$-Bgt to the intact cells. BgtR arrival was determined in the absence and presence of different concentrations of 2-BP (Fig. 2b). In the absence of 2-BP, there was a linear rise in the number of BgtRs inserted over $18 \mathrm{hr}$. The arrival of surface BgtRs was slowed by treating the cells with increasing concentrations of 2-BP from 60 to $180 \mu \mathrm{M}$ and appeared to be completely blocked at $180 \mu \mathrm{M}$. However, there was a delay of $3 \mathrm{hr}$ after 2-BP was applied before the treatment affected BgtR insertion. Because Bgt arrival at the surface was monitored over $18 \mathrm{hr}$, it is possible that an increase in the surface BgtR turnover rate is contributing to the effect of 2-BP. To test this possibility, the rate of surface BgtR turnover was directly measured over $24 \mathrm{hr}$ and did not significantly change with treatment at the same 2-BP concentrations (Fig. $2 c$ ).

To assay whether block of $\alpha 7$ subunit palmitoylation is altering the transport of assembled BgtRs to the cell surface, we monitored the effects of 2-BP on intracellular BgtRs. Intracellular

BgtRs were assayed by first binding surface BgtRs on the intact cells with unlabeled Bgt. The cells were solubilized, and surface receptors were removed by immunoprecipitation with anti-Bgt antibodies. The intracellular pool of BgtRs were then bound with ${ }^{125} \mathrm{I}$-Bgt and precipitated with concanavalin A Sepharose. If 2-BP treatment only caused a block of BgtR transport to the surface or incorporation into the plasma membrane, we would expect increased accumulation of intracellular BgtRs to occur during 2-BP treatment. In fact, we observed the opposite effect. As shown in Figure $2 d$, we measured a progressive loss of new intracellular Bgt binding sites with increasing 2-BP concentrations, and with the application of $180 \mu \mathrm{M} 2-\mathrm{BP}$, there was an overall decrease in intracellular BgtRs after $18 \mathrm{hr}$ (Fig. 2d) compared with the approximately threefold increase observed in the absence of 2-BP. The effects of 2-BP on the rise of intracellular Bgt binding sites suggests that $\alpha 7$ subunit palmitoylation has a role in the formation of new BgtRs in the cells, a process that precedes transport of intracellular BgtRs to the cell surface. Such a mechanism can explain the $\sim 3 \mathrm{hr}$ delay observed in the 2 -BP block of BgtR surface expression, because the formation of new BgtRs takes 2-3 hr to complete, as shown in Figure $5 c$.

\section{$5-\mathrm{HT}_{3 \mathrm{~A}}$ and $\alpha 7 / 5-\mathrm{HT}_{3 \mathrm{~A}}$ subunits are palmitoylated in HEK cells}

To determine in more detail how $\alpha 7$ subunit palmitoylation affects BgtR biogenesis, we required higher levels of BgtR expression than could be achieved practically using the PC12 cells. As an alternative, we expressed chimeric subunits consisting of the $\mathrm{N}$-terminal half of $\alpha 7$ fused to the C-terminal half of $5-\mathrm{HT}_{3 \mathrm{~A}}$ receptor subunits. Unlike $\alpha 7$ subunits, $\alpha 7 / 5-\mathrm{HT}_{3 \mathrm{~A}}$ subunits assemble into functional BgtRs in HEK cells and do so at levels 30to 50-fold higher than $\alpha 7$ subunits in PC12 cells (Rangwala et al., 1997). Furthermore, the processing and assembly of $\alpha 7 / 5-\mathrm{HT}_{3 \mathrm{~A}}$ subunits expressed in HEK cells appears to be similar to that of the endogenous $\alpha 7$ subunits expressed in PC12 cells and rat brain (Rakhilin et al., 1999; Drisdel and Green, 2000). Because of the high levels of expression in HEK cells, we were able to perform metabolic labeling of HA epitope-tagged $\alpha 7 / 5-\mathrm{HT}_{3 \mathrm{~A}}$ subunits with ${ }^{3} \mathrm{H}$-palmitate (Fig. $3 a$, lane 2). At similar levels of expression (Fig. 3a, compare lanes 4 and 5), we were unable to label $\alpha 7$ subunits with ${ }^{3} \mathrm{H}$-palmitate (Fig. $3 a$, lane 1). Hydroxylamine treatment removed ${ }^{3} \mathrm{H}$-palmitate from $\alpha 7 / 5-\mathrm{HT}_{3 \mathrm{~A}}$ subunits (Fig. $3 a$, compare lanes 2 and 3 ), demonstrating that palmitoylation is occurring via a thioester bond between palmitate and $\alpha 7 / 5-\mathrm{HT}_{3 \mathrm{~A}}$ cysteine residues.

To determine the stoichiometry of palmitoylation, we labeled Bgt-Sepharose-purified $\alpha 7 / 5-\mathrm{HT}_{3 \mathrm{~A}}$ subunits with ${ }^{3} \mathrm{H}-\mathrm{NEM}$ after hydroxylamine treatment (Fig. $3 b$, lane 1 ), and the amount of ${ }^{3} \mathrm{H}-\mathrm{NEM}$ specifically incorporated was determined. In parallel, the amount of ${ }^{125} \mathrm{I}$-Bgt binding to the same sized sample was measured. Combining both measurements, we estimated that the $\alpha 7 / 5-\mathrm{HT}_{3 \mathrm{~A}}$ subunits are palmitoylated with a stoichiometry of 1.4 pmol palmitate per pmol subunit (Table 1). As with the 2-BP data, these results show a strong correlation between subunit palmitoylation and the ability to express functional BgtRs. $\alpha 7 / 5-$ $\mathrm{HT}_{3 \mathrm{~A}}$ subunits, which form functional BgtRs in HEK cells, are highly palmitoylated at levels comparable with $\alpha 7$ subunits expressed in PC1 2 cells, whereas $\alpha 7$ subunits expressed in the same cells are not significantly palmitoylated and do not form functional BgtRs.

Similar experiments were performed to assay whether $5-\mathrm{HT}_{3 \mathrm{~A}}$ subunits expressed in HEK cells are palmitoylated. $5-\mathrm{HT}_{3 \mathrm{~A}}$ receptors are members of the same molecular family as nicotinic re- 
a
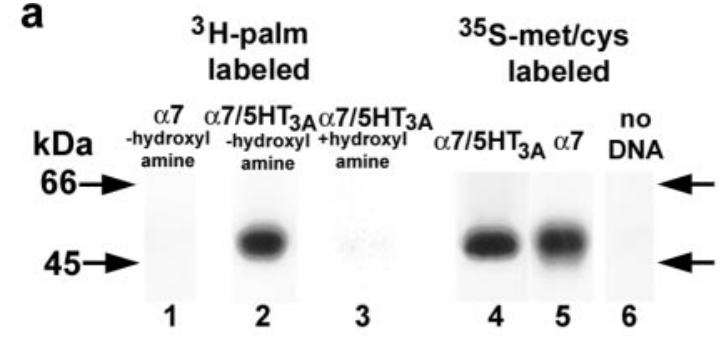

b

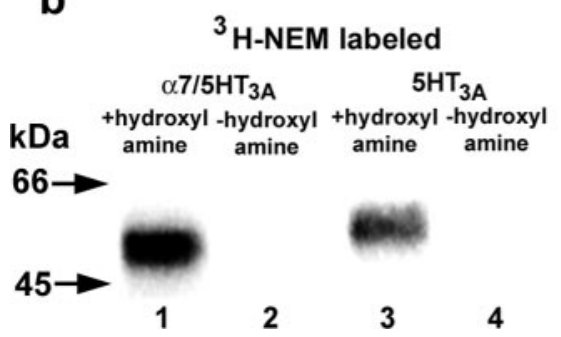

Immunoblot

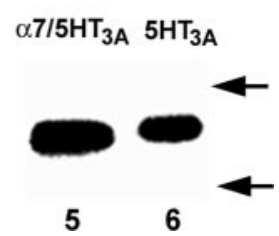

Figure 3. The palmitoylation of $\alpha 7, \alpha 7 / 5-\mathrm{HT}_{3 \mathrm{~A}}$, and $5-\mathrm{HT}_{3 \mathrm{~A}}$ subunits expressed in HEK cells. $a$, The palmitoylation of $\alpha 7$ and $\alpha 7 / 5-\mathrm{HT}_{3 \mathrm{~A}}$ subunits assayed by metabolic labeling with ${ }^{3} \mathrm{H}$ palmitate (lanes 1 and 2). Treatment of ${ }^{3} \mathrm{H}$-palmitate-labeled $\alpha 7 / 5-\mathrm{HT}_{3 \mathrm{~A}}$ subunits with hydroxylamine cleaved all ${ }^{3} \mathrm{H}$-palmitate from the subunits (lane 3). In parallel, $\alpha 7 / 5-\mathrm{HT}_{3 \mathrm{~A}}$ and $\alpha 7$ subunit synthesis was measured by ${ }^{35} \mathrm{~S}$-labeling (lanes 4 and 5 ). No labeling was observed in untransfected cells (lane 6). $\alpha 7 / 5-\mathrm{HT}_{3 \mathrm{~A}}$ and $\alpha 7$ were precipitated with Bgt-Sepharose affinity resin or anti-HA antibodies, respectively. $b$, The palmitoylation of $\alpha 7 / 5-\mathrm{HT}_{3 \mathrm{~A}}$ and $5-\mathrm{HT}_{3 \mathrm{~A}}$ subunits assayed by ${ }^{3} \mathrm{H}$-NEM labeling (lanes 1 and 3). No ${ }^{3} \mathrm{H}-\mathrm{NEM}$ labeling was observed in the absence of hydroxylamine treatment (lanes 2 and 4 ), which is required for specific ${ }^{3} \mathrm{H}$-NEM labeling of palmitoylation sites. Expression levels of $\alpha 7 / 5-\mathrm{HT}_{3 \mathrm{~A}}$ and $5-\mathrm{HT}_{3 \mathrm{~A}}$ subunits were assessed by immunoblot analysis (lanes 5 and 6 ). ${ }^{3} \mathrm{H}$-NEM labeled 5 - $\mathrm{HT}_{3 \mathrm{~A}}$ subunits at levels approximately equal to that of $\alpha 7 / 5-\mathrm{HT}_{3 \mathrm{~A}}$ subunits, accounting for differences in expression.

ceptors with a similar subunit membrane topology and a pentameric structure (Maricq et al., 1991) and like $\alpha 7 / 5-\mathrm{HT}_{3 \mathrm{~A}}$ subunits, can assemble into functional receptors in HEK cells. HA-tagged $5-\mathrm{HT}_{3 \mathrm{~A}}$ subunits were immunoprecipitated with anti-HA antibodies and treated with hydroxylamine. The palmitoylation sites were labeled with ${ }^{3} \mathrm{H}-\mathrm{NEM}$ (Fig. 3b, lane 3), and the amount of ${ }^{3} \mathrm{H}$-NEM incorporated was determined by scintillation counting. Without hydroxylamine treatment, no ${ }^{3} \mathrm{H}-\mathrm{NEM}$ labeling was observed (Fig. 3b, lane 4). Using anti-HA antibodies, the amount of $5-\mathrm{HT}_{3 \mathrm{~A}}$ subunit protein present was estimated by quantifying immunoblot bands relative to that of the $\alpha 7 / 5-\mathrm{HT}_{3 \mathrm{~A}}$ subunits (Fig. 3b, lanes 5 and 6). The amount of $\alpha 7 / 5-\mathrm{HT}_{3 \mathrm{~A}}$ was measured using ${ }^{125} \mathrm{I}$-Bgt binding from which the stoichiometry of $5-\mathrm{HT}_{3 \mathrm{~A}}$ subunit palmitoylation was estimated to be $1.2 \mathrm{pmol}$ palmitate per pmol subunit (Table 1). Thus, for $\alpha 7, \alpha 7 / 5-\mathrm{HT}_{3 \mathrm{~A}}$, and $5-\mathrm{HT}_{3 \mathrm{~A}}$ subunits, functional receptor expression correlated with subunit palmitoylation at a stoichiometry of approximately one palmitate per subunit, whereas subunits that did not assemble into functional receptors palmitoylated at levels $\sim 100$-fold less.

\section{Palmitoylation occurs during BgtR assembly in the ER}

We performed additional experiments on $\alpha 7 / 5-\mathrm{HT}_{3 \mathrm{~A}}$ subunits from HEK cells and $\alpha 7$ subunits from PC12 cells to determine whether palmitoylation is occurring during BgtR assembly. Both subunits are transformed during assembly from a state in which free sulfhydryl groups on cysteine residues are reactive to a state in which the cysteines are nonreactive (Rakhilin et al., 1999). This cysteine state change can be assayed by solubilizing the subunits without NEM treatment to alkylate free sulfhydryls and analyzing the subunits on nonreducing SDS-PAGE. Under these condi- tions, subunits with reactive free sulfhydryls crosslink with each other and other proteins into high molecular weight aggregates, whereas subunits with nonreactive cysteines remain as monomers or disulfide-bonded dimers, trimers, tetramers, or pentamers. The two states of the $\alpha 7 / 5-\mathrm{HT}_{3 \mathrm{~A}}$ subunits are displayed on nonreducing gels in Figure $4 a$ (lane 2) in which all ${ }^{35} \mathrm{~S}$-methionecysteine metabolically labeled subunits were immunoprecipitated with anti-HA antibodies. Subunits in the reactive state migrate as the aggregates at the top of the gel and in the nonreactive state as the single subunits and disulfide-linked multimers. PC12 cell $\alpha 7$ subunits showed the same behavior as the $\alpha 7 / 5-\mathrm{HT}_{3 \mathrm{~A}}$ subunits, although not as well resolved, migrating as aggregates or disulfide-linked multimers on nonreducing gels (Fig. $4 b$, lane 2 ). We have shown previously that the subunit aggregates are precursors that are transformed into single subunits or disulfidelinked multimers (dimers to pentamers) during receptor assembly when the subunits form Bgt binding sites (Rakhilin et al., 1999). As shown in Figure 4, $a$ and $b$, only single subunits or disulfide-linked multimers are precipitated when we specifically select for the Bgt-binding subunits with Bgt-Sepharose. This transformation between states is observed for $\alpha 7 / 5-\mathrm{HT}_{3 \mathrm{~A}}$ subunits and $\alpha 7$ subunits in PC12 cells but not for $\alpha 7$ subunits in HEK cells (Rakhilin et al., 1999; Drisdel and Green, 2000). The cysteine state change, therefore, correlates with the formation of functional BgtRs during assembly. If ${ }^{3} \mathrm{H}-\mathrm{NEM}$ labeling of palmitoylation sites is performed on $\alpha 7 / 5-\mathrm{HT}_{3 \mathrm{~A}}$ or $\alpha 7$ subunits, the aggregates, precursors of Bgt-binding subunits, are not palmitoylated, whereas the Bgt-binding subunits are palmitoylated (Fig. $4 a, b$, lanes 3 and 4 ).

The precipitation and ${ }^{3} \mathrm{H}-\mathrm{NEM}$ labeling of $\alpha 7 / 5-\mathrm{HT}_{3 \mathrm{~A}}$ and $\alpha 7$ subunits in Figure 4, $a$ and $b$, did not distinguish between newly assembled, intracellular BgtRs and assembled BgtRs at the cell surface. Different cellular pools of $\alpha 7 / 5-\mathrm{HT}_{3 \mathrm{~A}}$ subunits were purified to test whether we observed differences in palmitoylation of these subunits pools. To isolate cell-surface BgtRs, intact cells were bound with a saturating concentration of Bgt, solubilized, and receptors were immunoprecipitated with anti-Bgt antibodies. The solubilized pool of subunits depleted of surface receptors was then treated with excess Bgt-Sepharose to isolate intracellular Bgt-binding subunits. Finally, the remaining subunits, predominantly unassembled, were precipitated with anti-HA or anti- $\alpha 7$ antibodies. Subunits isolated from each pool were treated with hydroxylamine and labeled with ${ }^{3} \mathrm{H}-\mathrm{NEM}$ (Fig. 4c, d, lanes 1-3). We observed significant differences in the level of palmitoylation between the different subunit pools. The palmitoylation sites of the intracellular BgtRs were most highly labeled by ${ }^{3} \mathrm{H}-\mathrm{NEM}$ (Fig. $4 c, d$, lane 2). On average, the stoichiometry of palmitoylation of intracellular PC12 BgtRs was $2.6 \mathrm{pmol}{ }^{3} \mathrm{H}-\mathrm{NEM} / \mathrm{pmol}$ subunit and $2.2 \mathrm{pmol}{ }^{3} \mathrm{H}-\mathrm{NEM} / \mathrm{pmol}$ subunit for $\alpha 7 / 5-\mathrm{HT}_{3 \mathrm{~A}}$ BgtRs (Table 1), which indicates that two to three different cysteine residues on intracellular, Bgt-binding subunits are palmitoylated.

Although the intracellular BgtRs, which are predominantly precursors of surface BgtRs, were highly palmitoylated, surface BgtRs were palmitoylated much less (Fig. $4 c, d$, lane 1 ). The stoichiometry of palmitoylation of surface PC12 BgtRs was below the limits of resolution and $0.15 \mathrm{pmol}{ }^{3} \mathrm{H}-\mathrm{NEM} / \mathrm{pmol}$ subunit for $\alpha 7 / 5-\mathrm{HT}_{3 \mathrm{~A}}$ BgtRs (Table 1), 14-fold lower than for intracellular receptors. These results indicate that highly palmitoylated, newly assembled BgtRs are depalmitoylated during transport to and/or soon after arrival at the cell surface. We also analyzed the palmitoylation of the intracellular subunits that had not formed Bgt binding sites and are predominantly unassembled subunits. The stoichiometry of their palmitoylation was $0.5 \mathrm{pmol}{ }^{3} \mathrm{H}-\mathrm{NEM} /$ 

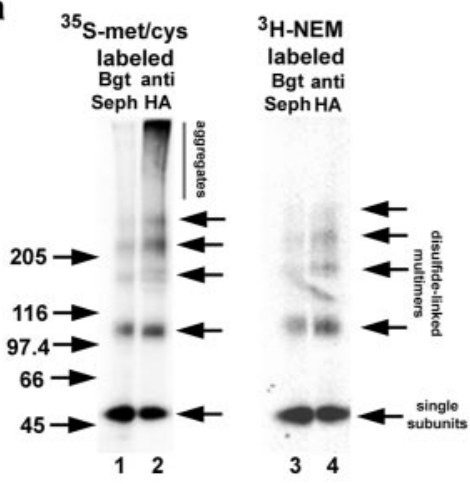

C

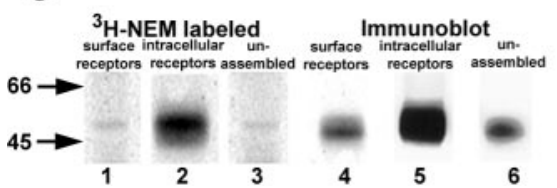

b
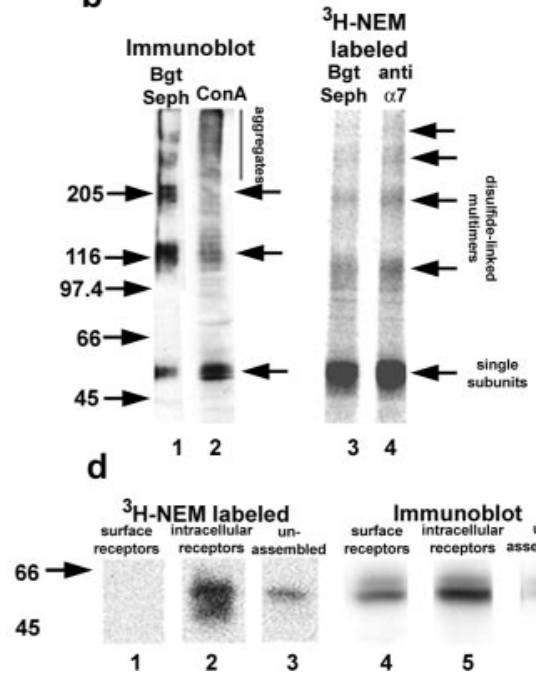

Figure 4. Palmitoylation occurs during assembly of $\alpha 7 / 5-\mathrm{HT}_{3 \mathrm{~A}}$ subunits. $a, \alpha 7 / 5-\mathrm{HT}_{3 \mathrm{~A}}$ subunits were pulse labeled with ${ }^{35}$ S-methionine (met) - cysteine (cys) for $1 \mathrm{hr}$ and then chased for $1 \mathrm{hr}$ and analyzed on nonreducing SDS-PAGE (lanes 1 and 2). When Bgt-binding subunits were precipitated with Bgt-Sepharose (Seph) (lane 1), a ladder of $\alpha 7 / 5-\mathrm{HT}_{3 \mathrm{~A}}$ subunits (single subunits and disulfide-bonded multimers) was observed. When all subunits were precipitated with anti-HA antibodies (lane 2), an additional set of subunits was observed that migrated as aggregates and were the subunit precursors of the Bgt-binding subunits. When the palmitoylation sites on $\alpha 7 / 5-\mathrm{HT}_{3 \mathrm{~A}}$ subunits were ${ }^{3} \mathrm{H}-\mathrm{NEM}$ labeled and the subunits were precipitated with either Bgt-Sepharose (lane 3) or anti-HA antibodies (lane 4), only the ladder of subunits was observed, which are predominately the Bgt-binding subunits. Aggregates, which are the precursors of the Bgt-binding subunits, were not labeled (lane 4).b, PC12 BgtRs precipitated with Bgt-Sepharose and immunoblotted with anti- $\alpha 7$ antibodies migrate as a ladder of single subunits and disulfide-linked multimers (lane 1). Concanavalin A (ConA)-agarose precipitation of $\alpha 7$ subunits followed by immunoblotting with anti- $\alpha 7$ antibodies shows subunits that migrate as a ladder as well as disulfide bonded aggregates (lane 2). When $\alpha 7$ subunits from PC12 cells were precipitated with Bgt-Sepharose (lane 3) or anti- $\alpha 7$ antibodies (lane 4) and labeled with ${ }^{3} \mathrm{H}-\mathrm{NEM}$, only a ladder of single subunits and disulfide-linked multimers was observed. Arrows on the right indicate the position of $\alpha 7 / 5-\mathrm{HT}_{3 \mathrm{~A}}$ and $\alpha 7$ subunit single subunits, disulfide-linked dimers, trimers, tetramers, and pentamers. $c, d$, Palmitoylation of different cellular pools. We performed three sequential precipitations to isolate cell-surface BgtRs (lane 1), intracellular BgtRs (lane 2), and unassembled subunits (lane 3) from $\alpha 7 / 5-\mathrm{HT}_{3 \mathrm{~A}}$-expressing cells ( $c$ ) or PC12 cells ( $d$ ), after which the subunits in the different pools were labeled with ${ }^{3} \mathrm{H}-\mathrm{NEM}$ to assay palmitoylation. In parallel, a combination of immunoblot analysis and ${ }^{125} \mathrm{I}-\mathrm{Bgt}$ binding was used to estimate subunit levels in each pool. Lanes 4, 5, and 6 represent immunoblots of cell surface, intracellular, and unassembled subunits, respectively, stained with anti-HA antibodies or anti- $\alpha 7$ antibodies. Estimates of the surface and intracellular Bgt-binding pools were obtained by ${ }^{125} \mathrm{I}$-Bgt binding (data not shown).

pmol subunit for PC12 $\alpha 7$ subunits and $0.36 \mathrm{pmol}{ }^{3} \mathrm{H}-\mathrm{NEM} /$ pmol subunit for $\alpha 7 / 5-\mathrm{HT}_{3 \mathrm{~A}}$ subunits (Table 1 ), or five- to sixfold less that of the intracellular BgtRs. This result reinforces the idea that $\alpha 7$ and $\alpha 7 / 5-\mathrm{HT}_{3 \mathrm{~A}}$ subunits are not palmitoylated immediately after their synthesis but are palmitoylated during assembly as Bgt binding sites are formed on the subunits.

To address where in the cells palmitoylation of intracellular BgtRs is occurring, experiments were performed to identify the location of intracellular BgtRs. PC12 cells (Fig. 5a) and cells expressing $\alpha 7 / 5-\mathrm{HT}_{3 \mathrm{~A}}$ subunits (Fig. $5 b$ ) were fixed, permeabilized, and stained with fluorescent-labeled Bgt. Displayed in Figure 5, $a$ and $b$, are confocal microscopy images of two different sets of cells that typified the Bgt staining. In PC12 cells, BgtRs showed a punctate staining pattern throughout the cell (Fig. 5ai,iv). Staining with anti-KDEL to mark the ER was more extensive than the BgtR staining (Fig. 5aii,v), but all of the BgtR staining colocalized with the anti-KDEL staining as shown by merged images (Fig. $5 a i i i, v i)$. Similar results were obtained with cells expressing $\alpha 7 / 5$ $\mathrm{HT}_{3 \mathrm{~A}}$ subunits. More prominent rim staining of surface BgtRs was obtained in these cells (Fig. 5bi,iv) compared with the PC12 cells, which did not colocalize with anti-KDEL staining of the ER (Fig. 5aiii,vi). However, intracellular fluorescent-Bgt staining prominent in a perinuclear ring and as discrete puncta throughout the cell did colocalize with anti-KDEL (Fig. 5biii,vi). The results are

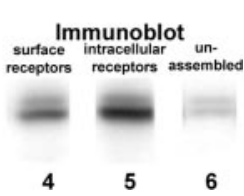

consistent with intracellular BgtRs existing predominantly in or closely associated with the ER in the cells.

To further test whether intracellular BgtRs are found in the ER, we assayed the endoH sensitivity of BgtRs. EndoH cleaves the oligosaccharide chains of ER proteins but not after oligosaccharide trimming in the Golgi. Cells expressing $\alpha 7 / 5-\mathrm{HT}_{3 \mathrm{~A}}$ subunits were metabolically labeled and chased to monitor BgtR expression. Intracellular BgtRs were separated from surface BgtRs as in Figure 4c. Surface BgtRs were resistant to endoH cleavage (data not shown). In contrast, intracellular BgtRs were cleaved by endoH as shown in Figure 5c. Initially, all intracellular BgtRs were cleaved, and with time an increasing percentage of the subunits became endoH resistant, consistent with Bgt binding site formation in the ER followed by transport to the surface through the Golgi apparatus.

\section{Discussion}

Compared with other protein posttranslational modifications, studies of palmitoylation are still in their infancy. The mechanisms by which proteins are palmitoylated are now being worked out, and a relatively small but growing number of proteins have been identified as palmitoylated. For cytoplasmic proteins, the process of palmitoylation, in large part, regulates associations with cell membranes. However, functions of palmitoylation are not well established for integral membrane proteins such as BgtRs. In this paper, we describe a novel function for protein palmitoylation: the regulation of BgtR expression during assembly in the ER. We made use of techniques developed recently in our laboratory that are more sensitive than other assays for palmitoylation (Drisdel and Green, 2004). Using these techniques, we measured the stoichiometry of palmitoylation of different LGIC subunits and assayed palmitoylation of BgtRs purified from rat brain, demonstrating for the first time the palmitoylation of a neurotransmitter receptor from brain. Other LGICs were previously found to be palmitoylated, muscle nicotinic AChRs in the $\mathrm{BC}_{3} \mathrm{H} 1$ cells (Olsen et al., 1984), glutamate receptor 6 subunits expressed in HEK and Sf9 cells (Pickering et al., 1995), and most recently, GABA $\mathrm{A}$ receptors expressed in HEK cells (Keller et al., 2004). It is likely that the palmitoylation of other LGICs will be characterized with the application of more sensitive techniques. With the recent evidence that LGIC assembly and trafficking are key processes underlying long-lasting changes in synaptic strength (Barry and Ziff, 2002; Malinow and Malenka, 2002; Sheng and Kim, 2002), the palmitoylation of LGIC subunits may have a role in regulating these processes.

Using the new techniques to assay palmitoylation, we addressed at what point in BgtR biogenesis $\alpha 7$ subunits are palmitoylated and where in the cell palmitoylation occurs. By isolating different subcellular pools of $\alpha 7 / 5-\mathrm{HT}_{3 \mathrm{~A}}$ and $\alpha 7$ subunits, we found that early subunit precursors (subunit aggregates) are not 
palmitoylated, and that the pool of unassembled subunits and/or assembling subunits that have not yet formed Bgt binding sites are poorly palmitoylated (Table 1). In contrast, intracellular BgtRs are highly palmitoylated, and inhibition of $\alpha 7$ subunit palmitoylation in PC12 cells blocks formation of new Bgt binding sites. These results, together with our evidence that intracellular BgtRs subunits are located in the ER, indicate that palmitoylation of the $\alpha 7$ subunit occurs during receptor assembly in the ER and that it has a role in formation of functional BgtRs. This conclusion is consistent with what is known about the formation of Bgt binding sites on muscle-type nicotinic receptors, which are highly homologous to $\alpha 7$ receptors in both sequence and structure (Karlin, 2002). For the muscle-type nicotinic receptors, formation of Bgt binding sites occurs during the assembly of the receptor in the ER and is preceded by a series of folding and processing events that appear to be required for the subunits to achieve Bgtbinding conformation (Green and Millar, 1995). The formation of Bgt binding sites on $\alpha 7 / 5-\mathrm{HT}_{3 \mathrm{~A}}$ subunits occurs with similar kinetics and requires some of the same processing events (Rakhilin et al., 1999).

We have not tested directly whether palmitoylation is affecting recycling of surface receptors. Presently, it is not known whether surface BgtRs recycle. Studies have found no evidence that muscle nicotinic receptors recycle (Gardner and Fambrough, 1979), but that does not exclude the possibility that neuronal BgtRs do. However, several findings in this manuscript suggest that receptor palmitoylation does not significantly regulate BgtR recycling if it is occurring. First, unlabeled Bgt was used to mask BgtRs already at the cell surface from the binding of ${ }^{125} \mathrm{I}$ Bgt. As a result, the increase of ${ }^{125} \mathrm{I}-\mathrm{Bgt}$ surface binding in Figure $2 b$ is predominantly a measure of the insertion of newly assembled receptors, because most surface, and thus recycled, receptors were bound by unlabeled Bgt. Therefore, BgtR recycling does not appear to contribute significantly to the block of ${ }^{125} \mathrm{I}$-Bgt surface binding by 2-BP. Second, if bromopalmitate blocks recycling, it must be blocking the process of endocytosis or subsequent steps before or during reinsertion of recycled BgtRs. If endocytosis were blocked by 2-BP, the rate of surface BgtR degradation would be expected to be reduced. Such a reduction in the degradation rate does not occur. If reinsertion were blocked, then the number of intracellular Bgt binding sites would be expected to rise. In fact, we observed the opposite effect, a decrease in intracellular Bgt binding, consistent with a block of BgtR assembly. Finally, if significant BgtR recycling were occurring, we would expect to see a sizeable pool of intracellular BgtR in endo-

\section{b} and autoradiography.
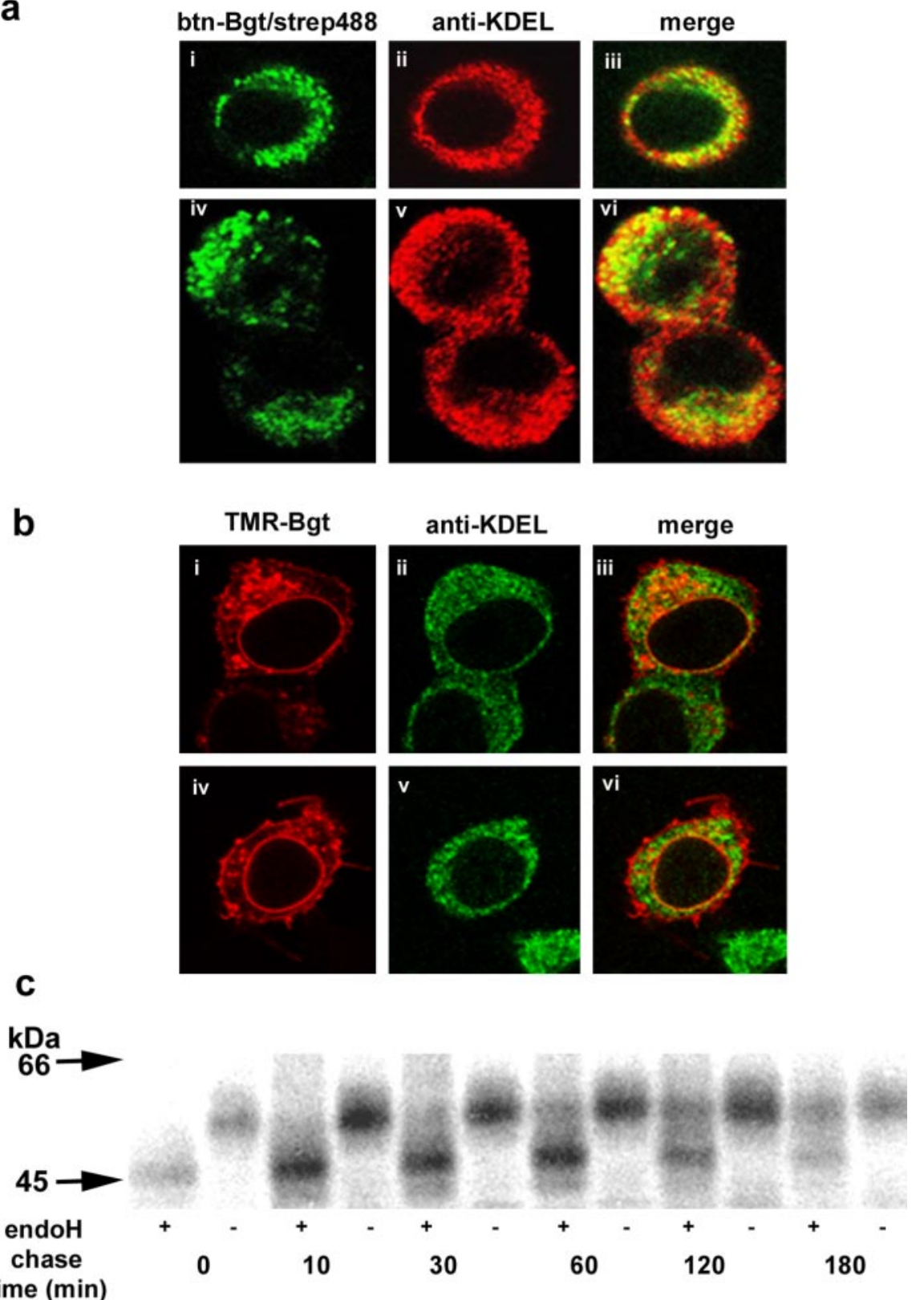

Figure 5. Intracellular BgtRs are predominantly in the ER. $a$, Permeabilized PC12 cells were stained with btn-Bgt and strep488 (green; $i, i v)$. Cells were stained with anti-KDEL antibody (red; $i i, v)$, which is specific for ER-resident proteins. Merged images of btn-Bgt and anti-KDEL staining (iii, vi). b, Permeabilized cells expressing $\alpha 7 / 5-\mathrm{HT}_{3 \mathrm{~A}}$ subunits were stained with TMR-Bgt (red), which labels BgtRs at the plasma membrane and intracellular compartments $(i, i v)$. ER staining with anti-KDEL (green; ii, v). Merged images of the TMR-Bgt and anti-KDEL antibody staining (iii, vi). c, $\alpha 7 / 5-\mathrm{HT}_{3 \mathrm{~A}}$-expressing cells were pulse labeled for 15 min and chased for the indicated times. Purified intracellular receptors were treated with or without endoH followed by SDS-PAGE

somes. This does not appear to be the case because most intracellular BgtRs appear to be in the ER.

Our results with the $\alpha 7 / 5-\mathrm{HT}_{3 \mathrm{~A}}$ subunits and $\alpha 7$ subunits from PC12 cells provide some of the first evidence that proteins can be palmitoylated at or in the ER. Previous studies investigating where certain proteins, such as viral glycoproteins, SNAP-25, and GAP-43, are palmitoylated in cells have concluded that palmitoylation occurs at the plasma membrane and along the secretory pathway with the exception of the ER (Bijlmakers and Marsh, 2003). Evidence indicating that palmitoylation can also occur in the ER is the discovery of two ER-localized proteins in 


\section{a. $\alpha 7$ in PC12 cells}

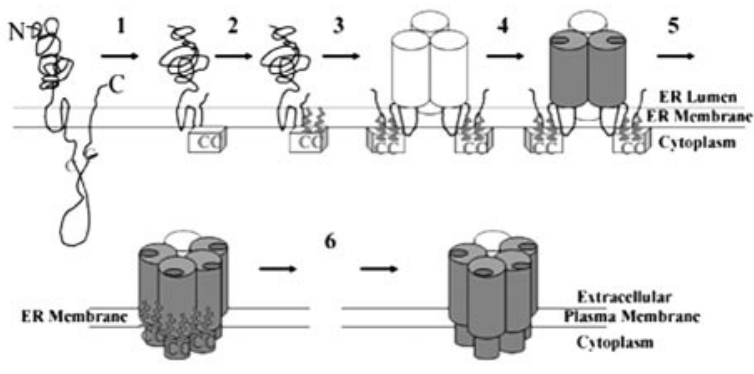

b. $\alpha 7$ in HEK cells

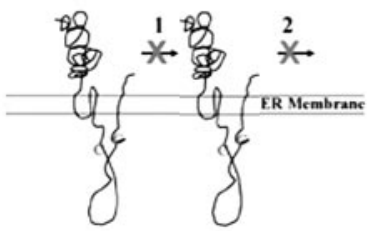

\section{c. $\alpha 7 / 5 \mathrm{HT}_{3 \mathrm{~A}}$ in HEK cells}

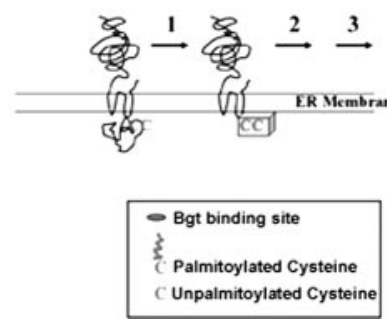

Figure 6. A model of $\alpha 7$ subunit palmitoylation during BgtR assembly. $a$, In cells capable of $\alpha 7$ BgtR expression (PC12 cells, neurons), $\alpha 7$ subunits begin in a conformation in which the cysteines $(C)$ at potential palmitoylation sites are inaccessible to palmitoylation. In step 1, $\alpha 7$ subunits undergo an initial folding and processing step that changes the conformation of these cysteines so that they become accessible to palmitoylation. In step 2, the cysteines are palmitoylated, which allows the subsequent assembly events that result in functional BgtRs (steps 3-5). After release from the ER and transport to the plasma membrane (step 6), BgtRs are depalmitoylated, which does not appear to affect receptor function. $b$, In cells incapable of $\alpha 7$ BgtR expression (HEK cells), step 1 does not occur because of the absence of the enzymes that mediate the necessary folding and processing. Without the conformational change of step 1, $\alpha 7$ subunits are not palmitoylated and functional, and Bgt-binding receptors are not assembled. $c$, In HEK cells, $\alpha 7 / 5-\mathrm{HT}_{3 \mathrm{~A}}$ subunits begin in a conformation in which the cysteines at potential palmitoylation sites are accessible to palmitoylation and do not have to undergo step 1 for the cysteines to be palmitoylated. Palmitoylation of $\alpha 7 / 5-\mathrm{HT}_{3 \mathrm{~A}}$ subunits allows the rest of the steps of BgtR assembly to occur.

yeast, Erf4p and Erf2p, which function as palmitoyltransferases. The two proteins form a complex that appears to palmitoylate a yeast homolog of Ras (Zhao et al., 2002).

BgtRs composed of $\alpha 7$ subunits are unique among LGICs and other ion channels in that the correct complement of subunits is not sufficient to achieve functional receptor expression. Additional subunit processing is required for functional expression, and it only occurs in certain neurons and specialized cells. Here, we found that palmitoylation of $\alpha 7$ subunits is part of the processing of these subunits that results in BgtR functional expression. However, protein palmitoylation occurs in most, if not all, cells, and our results, therefore, do not provide an explanation for why BgtR functional expression only occurs in certain cells. In HEK cells, which are incapable of BgtR expression, $\alpha 7$ subunits were not significantly palmitoylated. Yet palmitoylation of $\alpha 7 / 5$ $\mathrm{HT}_{3 \mathrm{~A}}$ chimeras and $5-\mathrm{HT}_{3 \mathrm{~A}}$ subunits does occur in HEK cells and at stoichiometries similar to the palmitoylation of $\alpha 7$ subunits in PC12 cells, which are permissive for BgtR expression. Thus, there is no defect that prevents protein palmitoylation in the nonpermissive HEK cells. Instead, additional processing events determine whether $\alpha 7$ subunit palmitoylation occurs.

A model based on our data describing when and where palmitoylation of $\alpha 7$ is occurring and the role it plays in BgtR expression in specialized cells is shown in Figure 6. The $\alpha 7$ subunits, whether expressed in cells competent for BgtR expression (Fig. $6 a$ ) or in cells incapable of BgtR expression (Fig. 6b), begin as nonpalmitoylated, unassembled subunits just after synthesis at the ER membrane. Similarly, the $\alpha 7 / 5-\mathrm{HT}_{3 \mathrm{~A}}$ chimeric subunits expressed in cells incapable of BgtR expression (Fig. $6 c$ ) begin as nonpalmitoylated, unassembled subunits. The initial step, although not directly involved in the palmitoylation of $\alpha 7$ subunits, is required before subunits can be palmitoylated. We envision this step as a conformational change that alters cysteines at sites of palmitoylation such that the cysteines change from inaccessible to accessible to the enzymes that catalyze palmitoylation. It is this initial processing of $\alpha 7$ subunits that occurs in permissive cells, such as PC12 cells (Fig. $6 a$ ), but not other cells, such as HEK cells (Fig. 6b). HEK cells lack the ER enzymes or chaperone proteins that mediate this processing. However, $\alpha 7 / 5-\mathrm{HT}_{3 \mathrm{~A}}$ chimeras in HEK cells readily achieve a conformation allowing palmitoylation without the need for additional enzymes or chaperones (Fig. 6c). With the completion of step 1, palmitoylation can proceed (step 2). It is unknown whether the palmitoylation occurs when the subunits are unassembled as shown in the figure or on assembled intermediates such as shown in the next step of the model. After their palmitoylation, the subunits continue to assemble and mature. Based on studies of the muscle AChR assembly (Green and Wanamaker, 1998), we assume that Bgt-binding sites form on subunit trimers during assembly as shown in the model. Different conformations of the subunits result during assembly of BgtRs (Rakhilin et al., 1999), as indicated by differently shaded subunits.

In summary, functional expression of BgtRs is regulated by palmitoylation of $\alpha 7$ subunits during their assembly in the ER, and palmitoylation of $\alpha 7$ subunits is itself regulated by other post-translational processes. Whereas newly assembled BgtRs in the ER are highly palmitoylated, BgtRs at the plasma membrane are palmitoylated much less. BgtRs, therefore, undergo a process of depalmitoylation after their departure from the ER (Fig. 6a). Because surface BgtRs are functional, it would appear that palmitoylation in the ER is required to produce functional receptors but not necessary for function once the receptors are released from the ER. Note that subunit depalmitoylation was observed in HEK cells and PC12 cells. In chick ciliary ganglion neurons in which BgtRs are found clustered in lipid rafts (Shoop et al., 1999; Bruses et al., 2001), palmitoylation of $\alpha 7$ subunits might be maintained and function in BgtR trafficking and insertion into lipid rafts, as has been found with other palmitoylated membrane proteins.

\section{References}

Arrendondo J, Thuong-Nguyen V, Chernyavsky AI, Bercovich D, OrrUrtreger A, Kummer W, Lips K, Vetter DE, Grando SA (2002) Central role of $\alpha 7$ nicotinic receptor in differentiation of the stratified squamous epithelium. J Cell Biol 159:325-336.

Barry MF, Ziff EB (2002) Receptor trafficking and the plasticity of excitatory synapses. Curr Opin Neurobiol 12:279-286.

Bijlmakers MJ, Marsh M (2003) The on-off story of protein palmitoylation. Trends Cell Biol 13:32-42.

Bizzozero OA, Malkoski SP, Mobarak C, Bixler HA, Evans JE (2002) Massspectrophotometric analysis of myelin proteolipids reveals new features of this family of palmitoylated membrane proteins. J Neurochem 81:636-645.

Blumenthal EM, Conroy WG, Romano SJ, Kassner PD, Berg DK (1997) Detection of functional nicotinic receptors blocked by $\alpha$-bungarotoxin on PC12 cells and dependence of their expression on post-translational events. J Neurosci 17:6094-6104.

Bruses JL, Chauvet N, Rutishauser U (2001) Membrane lipid rafts are necessary for the maintenance of the $\alpha 7$ nicotinic acetylcholine receptor in somatic spines of ciliary neurons. J Neurosci 21:504-512. 
Coleman RA, Rao P, Fogelsong RJ, Bardes ES (1992) 2-BromopalmitoylCoA and 2-bromopalmitate: promiscuous inhibitors of membranebound enzymes. Biochim Biophys Acta 1125:203-209.

Cooper S, Millar NS (1997) Host cell-specific folding and assembly of the neuronal nicotinic acetylcholine receptor $\alpha 7$ subunit. J Neurochem 68:2140-2151.

Corringer PJ, Galzi JL, Eisele JL, Bertrand S, Changeux JP, Bertrand D (1995) Identification of a new component of the agonist binding site of the nicotinic alpha 7 homooligomeric receptor. J Biol Chem 270:11749-11752.

Drisdel RC, Green WN (2000) Neuronal $\alpha$-bungarotoxin receptors are $\alpha 7$ subunit homomers. J Neurosci 20:133-139.

Drisdel RC, Green WN (2004) Labeling and quantifying sites of protein palmitoylation. Biotechniques 36:276-285.

Eertmoed A, Vajello YF, Green WN (1999) Transient expression of heteromeric ion channels. Methods Enzymol 293:564-585.

El-Husseini AD, Bredt DS (2002) Protein palmitoylation: a regulator of neuronal development and function. Nat Rev Neurosci 3:791-802.

El-Husseini AD, Schnell E, Dakoji S, Sweeney N, Zhou Q, Prange O, Gauthier-Campbell C, Aguilera-Moreno A, Nicoll RA, Bredt DS (2002) Synaptic strength regulated by palmitate cycling on PSD-95. Cell 108:849-863.

Gardner JM, Fambrough DM (1979) Acetylcholine receptor degradation measured by density labeling: effects of cholinergic ligands and evidence against recycling. Cell 16:661-674.

Green WN, Millar NS (1995) Ion-channel assembly. Trends Neurosci 18:280-287.

Green WN, Wanamaker (1998) Formation of the nicotinic acetylcholine receptor binding sites. J Neurosci 18:5555-5564.

Karlin A (2002) Emerging structure of the nicotinic acetylcholine receptors. Nat Rev Neurosci 3:102-114.

Keller CA, Yuan X, Panzanelli P, Martin ML, Alldred M, Sassoe-Pognetto M, Luscher B (2004) The $\gamma 2$ subunit of $\mathrm{GABA}_{\mathrm{A}}$ receptors is a substrate for palmitoylation by GODZ. J Neurosci 24:5881-5891.

Linder ME, Deschenes RJ (2003) New insights into the mechanisms of protein palmitoylation. Biochemistry 42:4312-4320.

Malinow R, Malenka RC (2002) AMPA receptor trafficking and synaptic plasticity. Annu Rev Neurosci 25:103-126.

Maricq AV, Peterson AS, Brake AJ, Myers RM, Julius D (1991) Primary structure and functional expression of the 5HT3 receptor, a serotoningated ion channel. Science 254:432-437.
McGehee DS, Role LW (1995) Physiological diversity of nicotinic acetylcholine receptors expressed by vertebrate neurons. Annu Rev Physiol 57:521-546.

Olsen EN, Glaser G, Merlie JP (1984) $\alpha$ and $\beta$ subunits of the nicotinic acetylcholine receptor contain covalently bound lipid. J Biol Chem 259:5364-5367.

Picciotto MR, Caldarone DH, Brunzell DH, Zachariou V, Stevens TR, King SL (2001) Neuronal nicotinic acetylcholine receptor subunit knockout mice: physiological and behavioral phenotypes and possible clinical implications. Pharmacol Ther 92:89-108.

Pickering DS, Taverna FA, Salter W, Hampson DR (1995) Palmitoylation of the GluR6 kainate receptor. Proc Natl Acad Sci USA 92:12090-12094.

Qanbar R, Bouvier M (2003) Role of palmitoylation/depalmitoylation reactions in G-protein-coupled receptor function. Pharmacol Ther 97:1-33.

Rakhilin S, Drisdel RC, Sagher D, McGehee DS, Vallejo Y, Green WN (1999) $\alpha$-Bungarotoxin receptors contain $\alpha_{7}$ subunits in two different disulfidebonded conformations. J Cell Biol 146:203-217.

Rangwala F, Drisdel RC, Rakhilin S, Ko E, Atluri P, Harkins AB, Fox AP, Salman SB, Green WN (1997) Neuronal $\alpha$-bungarotoxin receptors differ structurally from other nicotinic acetylcholine receptors. J Neurosci 17:8201-8212.

Sargent P (1993) The diversity of neuronal nicotinic acetylcholine receptors. Annu Rev Neurosci 16:403-443.

Sheng M, Kim MJ (2002) Postsynaptic signaling and plasticity mechanisms. Science 298:776-780.

Shoop RD, Martone ME, Yamada N, Ellisman MH, Berg DK (1999) Neuronal acetylcholine receptors with $\alpha 7$ subunits are concentrated on somatic spines for synaptic signaling in embryonic chick ciliary ganglia. J Neurosci 19:692-704.

Swick AG, Janicot M, Cheneval-Kastelic T, McLenithan JC, Lane MD (1992) Promoter-cDNA-directed heterologous protein expression in Xenopus laevis oocytes. Proc Natl Acad Sci USA 89:1812-1816.

Webb Y, Hermida-Matsumoto L, Resh MD (2000) Inhibition of protein palmitoylation, raft localization, and $\mathrm{T}$ cell signaling by 2-bromopalmitate and polyunsaturated fatty acids. J Biol Chem 275:261-270.

Zhao L, Lobo S, Dong X, Ault AD, Deschenes RJ (2002) Erf4p and Erf2p form an endoplasmic reticulum-associated complex involved in the plasma membrane localization of yeast Ras proteins. J Biol Chem 277: 49352-49359. 